\title{
数種の平板理論の動特性（自由振動と分散特性）
}

\author{
に関する研究
}

\section{STUDY ON DYNAMIC CHARACTERISTICS (FREE VIBRATION AND DISPERSION RELATION) OF SEVERAL PLATE THEORIES}

\author{
平 島 健 一*・根 岸 嘉 和** \\ By Ken-ichi HIRASHIMA and Yoshikazu NEGISHI
}

\section{1. 緒言}

平板の面内および面外方向への動特性に関する研究は 従来より膨大な数の論文が発表され, それについての優 れた Review が Leissa によりまとめられており ${ }^{1)}$ ，そ こには曲げの古典理論の確立がなされて以降の実用的使 用に耐えると思われる，20 世紀に入ってから 1960 年代 までの全世界において発表された種々の形状,荷重条件, 境界条件を有する平板の固有值と固有モードに関する約 500 の文献についてのきわめて適切な整理がなされてい る. またその後の文献についても同氏2) (4)や Bert $^{5)}$ らに より整理が行われているが，それ以降においてもきわめ て多くの文献が量産されているのが現状である.

ところで, ここで平板理論, 特に振動する平板理論の 発達の歴史的経緯の概略を振り返っておこう(6) 12). ま ず, 1787 年 Chladni が振動する平板の nordal patterns を実験的に提示して以来, 板の振動に対する興味は多く の科学者や工学者を引きつけたが, 当時は平板の理論式 （いわゆる曲げの古典理論式）はまだ定式化されていな かった. そこで, フランス科学アカデミーは 1808 年 Chladni の公開実験に立ち合ったナポレオン皇帝の提案 を受けて，1811 年 10 月をその第 1 回目の期限として板 の振動理論の誘導および理論結果と Chladni の実験結 果との比較を㲘賞論文の課題とした. 三度にわたってそ れに応募した Sophie Germain (1776-1831) は曲げ振 動の等方性板に対する正しい基礎方程式を誘導するとと もに賞を獲得した (1815 年). 本文の 2. の式 (10) で 示される方程式は今では平板曲げの古典理論式ないしは Germain-Lagrange 方程式とよばれている（なお Lagrange の名が付される由縁は彼女の提出した最初の論文 に対して，誤りを発見し修正して正しい結果を与えると

\footnotetext{
* 正会員 工博 山梨大学助教授 工学部土木工学科

** 正会員 工修 福島工業高等専門学校講師 土木工学科
}

いう重要な貢献をしたことによる)。ほぼ時を同じくし $\tau$, Lagrange, Legendre, Navier, Fourier, Stokes, Poisson, Cauchy および Euler をはじめとして他の多く の著名な学者もこの課題に大きな興味を示した.

Germain の memoir の発行（1821 年）はまた曲げを 受ける薄板の適切な境界条件に関する長きにわたる論争 の出発でもあった. Poisson, St. Venant, W. Thomson (Kelvin), Tait, Mathieu, Boussinesq および Kirchhoff らは適切な境界条件の定式化に対して貢献をなしたが, ことに Kirchhoff による論文 (1850 年) は変分法に基づ いた板の方程式と正確な境界条件の完全な誘導を含んだ 優れたものであり, それには解の唯一性定理と Chladni の実験值に対する理論值との比較も含んでいるものであ った（なお Poisson は 1829 年に円形板の振動に関する 問題を解き, Chladni と同様の手法を用いた Savart の 粉体をまぶした平板に対する nordal patterns の実験結 果ときわめてよく一致することを検証した).

同じ時期に板の面内運動に関する研究も実施され, 伸 縮運動をする等方性薄板に対する支配方程式が Poisson により誘導された（1829 年）(これは本文中の式 (14) に提示されている). しかしながら，曲げ運動の場合と 異なってこの薄板の伸縮運動の問題はごく最近まであま り注目を集めなかった。

1889 年 Rayleigh ${ }^{13)}$ は平板理論の歷史に一つの転開 点を示す論文を発表した. その論文において, Rayleigh は線形弾性論から任意厚さの等質・等方の平板の振動を 決定したが，彼はまたそれらの結果が板厚零の極限にお いて薄板理論の結果となることを示すとともに, 波長が 零に近づくときには, 半無限体内の表面波 (Rayleighの 表面波)の結果にも帰着されることを示した. Rayleigh の定式化に基づいて $\mathrm{Lamb}^{14)}$ は厚板の波動伝播（Rayleigh-Lamb 波)の詳細について研究した. この Rayleigh-Lamb 波の特性振動数は構造部材に対しては 10 $\mathrm{kHz}$ もしくはそれ以上の大きさのものであるため, 当時 
はほとんど注目を集めなかった.

異方性板の波動・振動の研究の歷史は等方性に比べか なり遅れをとった. すなわち, 1829 年に薄い結晶板の 伸縮および曲げ振動に対する方程式が Cauchy により誘 導されたが，それから約半世紀の間はさしたる進展はみ られなかった. 19 世紀の終わりに近くなって, やっと結 晶物理学が実際的に始動し始め, それに伴った多くの新 発見の一つに, 1880 年の Curie 兄弟による piezoelectricity があるが, この piezoelectric な効果すなわち, electro-mechanical な連成効果は近代通信技術に重大な 衝撃を与えるとともに平板理論のさらなる発展に重要な 刺激をうながし，そのことが弾性表面波の伝搬特性を用 いた band-pass filter への応用による最近の注目すべき 遅延回路から多重通信にわたる広範囲の通信革命への幕 引き役をになって現在に至ることとなったのである ${ }^{17)}$.

ところで線形弾性論に基づいた運動する平板の境界值 問題に対する厳密解を見出すことは一般的な場合には不 可能であり, Rayleigh および Lamb は板の上下表面に 外力が作用しない無限に広がった板の厳密解を見出すこ とに成功したに過ぎなかった. 事実, たとえば板の端面 も応力自由の境界条件をもつ板（すなわち板の上下およ び端面のすべての境界で応力自由の板）に対しては，い まだに一般解が見出されていない. したがって, 解析的 な指針として取り組むべき課題は，境界を有する平板に 適するように弾性㛜密解の近似解を見出すか, あるいは 板の近似理論を閉じた形で求め得るように発展させるか である.

Cauchy（1829 年）および Poisson（1829 年）に従っ て, Mindlin は後者のアプローチを採用し, 1951 年彼 は等方性平板の曲げ振動に及ぼす回転慣性とせん断変形 の影響を含めた平板の近似理論を発表した ${ }^{18)}$.これはは りに対する Timoshenko 方程式と同等のレベルのもの であり現在では通常, 平板に対する Mindlin 方程式と よばれ，薄板に対する Germain-Lagrange 方程式（古 典平板理論）の一つの拡張として, かなりの高次の振動 数範囲に対しても適用できるものである（同じ年に Mindlin は異方性平板の曲げ理論も発表した ${ }^{19)}$ ). そし て Mindlin は 1955 年に板の面内, 面外を含めた振動 問題の理論的取扱いに関する総合報告 ${ }^{20)}$ を発表するに至 る. これはそれ以前の弾性厳密解と近似解法について鳥 瞰するとともに等質な等方および異方性平板の厳密解に 対する振動スペクトルの計算および近似解析理論につい ての取組み方の指針と幾つかの具体例を示したもので平 板の振動問題の研究において大きなエポックとなるもの であった（しかし，残念なことにいわゆる市販本の形で 公刊されなかったためにあまり知られていない). その 後も Mindlin とその協力者は平板, はりの波動・振動
に関する 40 以上の論文 ${ }^{21)}$ 発表して現在に至り，この 分野の発展に大きな貢献をしたのである. これ以降の発 展は本節の初めに述べた幾つかの Reviews's) そ) その他 ${ }^{22)}$ によってうかがうことができる。

以上のような歴史的経過を踏まえ, 主として本論文で 取り上げようとする課題は古典平板理論および Mindlin 理論を含めて，いわゆるせん断変形を含む板厚方向の諸 成分や回転慣性の効果等を考慮した面外 (曲げ) および 面内 (伸縮) 運動をする平板の近似理論に対する系統的 な提示と矩形板の自由振動および分散特性の問題につい てであり，取り上げた幾つかの理論から求められた計算 值を厳密解と比較し, その精度特性の検討を動的問題に 対して実施することである. なおここでは対象とする平 板を一定厚さの等質等方性弾性体に限定する.

\section{2. 動的な項を含む平板理論の概要}

静的な荷重が作用する平板理論の最近までの発達過程 およびそれらの代表的な理論式の概要と特徴および幾 つかの数值計算例について, 著者らは別論文で発表し

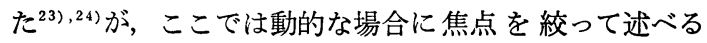
ことにする.これは先の静的な理論式に慣性力項を適切 に導入してやればよく，その一つとして，たとえば， Mindlin 理論 ${ }^{18)}$ はせん断変形を考虑した 静的平板理論 (Reissner 理論 ${ }^{25)}$ とは 異なり板厚方向のせん断応力分 布を一定值とする代償に, せん断補正係数 $\kappa^{2}$ を導入し た理論）に通常の上下方向の変位加速度による 慣性力 (translational inertia force) と断面の回転による慣性力 (rotatory inertia force) をともに導入することにより求 められるものである. したがって著者らの前論文 ${ }^{24)}$ 中の Table 1 で与えた各種の理論はすべて動的な平板理論へ の拡張が可能となる.ここでは主として GermainLagrange, Mindlin, Ambartsumyan ${ }^{26)}$, Schmidt ${ }^{27)}$, Voyiadjis-Baluch ${ }^{28)}$ および著者らによる General Higher-Order 理論 ${ }^{29)}$ 等のごく最近の提案になる諸理論を中 心にして述べ, さらに Vlasov による初期関数法（Method of Initial Function; MIF) の概要を説明し, 各理 論式間の関連性についても言及する.

まず，系統的な各理論式間の位置付けが可能となると いう理由から，はじめに Voyiadjis および Baluch の理 論 ${ }^{28)}$ (B-V 理論) を若干改良した理論 (修正 B-V 理 論）の支配方程式を取り上げよう.なお， $\mathrm{B}-\mathrm{V}$ 理論は いわゆる Kirchhoff-Love の仮定をはずし, 板厚方向の 成分 (せん断応力 $\tau_{x z}, \tau_{y z}$, 直応力 $\sigma_{z}$ および直ひずみ $\left.\varepsilon_{z}\right)$ の影響を定式化過程の段階で考慮し, 閉じた形の支 配式を導出したものであるが, 修正 B-V 理論は次の 2 点についてこれを改良したものである. すなわち， (1) 


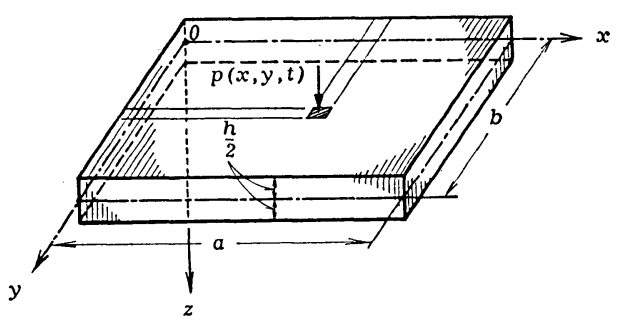

Fig. 1 Geometry of rectangular plate and rectangular Cartesian coordinate system $(x, y, z)$.

$\tau_{x z}, \tau_{y z}$ の放物線分布仮定をもとにして $\sigma_{z}$ の評価には 後出の三次元弾性論の運動方程式（20）を満たすように する, (2) $\varepsilon_{z}$ の評価に際し構成関係式 (Hooke の法則) を 用いるため必要となる面内直応力の和 $\sigma_{x}+\sigma_{y}$ の算定に あたって曲げモーメント和 $M=M_{x}+M_{y}$ に加えて，軸 力和 $N=N_{x}+N_{y}$ の影響も考慮することによって変位お よび応力の板厚方向の分布形の改善を図る. 順を追って このことを説明しよう.

いま Fig.1 のような座標系を設定し，平板の上表面 に鉛直下向きの外荷重 $p(x, y, t)$ が作用する場合を対 象とすれば，面外（板厚）方向に関連する上述の応力, ひずみは次のように与えられる.

$$
\left.\left.\begin{array}{rl}
\tau_{x z}= & \frac{3}{2 h} Q_{x}\left\{1-\left(\frac{2 z}{h}\right)^{2}\right\}, \\
\tau_{y z}= & \frac{3}{2 h} Q_{y}\left\{1-\left(\frac{2 z}{h}\right)^{2}\right\}, \\
\sigma_{z}= & -\frac{p}{4}\left\{2-3\left(\frac{2 z}{h}\right)+\left(\frac{2 z}{h}\right)^{3}\right\} \\
& -\frac{h}{4}\left\{\left(\frac{2 z}{h}\right)-\left(\frac{2 z}{h}\right)^{3}\right\} \rho \ddot{w}_{0},
\end{array}\right\} \ldots \ldots \ldots \ldots(1) .\left(\frac{2 z}{h}\right)^{3}\right\}-\frac{12 \nu}{E h} h^{3} z M
$$

ここに,

$$
\left.\begin{array}{l}
N=N_{x}+N_{y}=\int_{-h / 2}^{h / 2}\left(\sigma_{x}+\sigma_{y}\right) d z, \\
M=M_{x}+M_{y}=\int_{-h / 2}^{h / 2}\left(\sigma_{x}+\sigma_{y}\right) \cdot z d z .
\end{array}\right\}
$$

（上式で下線の項を省略したものが $\mathrm{B}-\mathrm{V}$ 理論である.)

ここに, $Q_{x}, Q_{y}$ は断面の面外方向せん断力, $\ddot{w}_{0}$ は板 中央面の鉛直変位を時間 $t$ によって 2 階偏微分したもの であり，また， $E ， \nu$ はそれぞれ弾性係数，ポアソン比 を表わす。

上式を出発点として動弾性学の基礎式に代入整理すれ ば, 最終的に平板の面外方向（曲げ）の支配方程式は次 式のようになる $\left(Q_{y}\right.$ に関する支配式は省略).

$$
Q_{x, x}+Q_{y, y}=-p+h \rho \ddot{w}_{0}-\frac{\nu \rho}{2 E} \ddot{M}+\frac{9 h^{2}}{160} \cdot \frac{\rho}{E} \ddot{p} \mid
$$

$$
\begin{aligned}
& -\frac{7 h^{3}}{480} \cdot \frac{\rho^{2}}{E} w_{0}^{(4)} \\
& Q_{x}-\frac{h^{2}}{10} \nabla^{2} Q_{x}+D \nabla^{2} w_{0, x} \\
& =-\left\{\frac{h^{2}(1+\nu)}{10(1-\nu)}-\frac{h^{2} \nu}{10(1-\nu)}\right\} p, x-\frac{h^{2}}{10} \cdot \frac{\rho}{G} \ddot{Q}_{x} \\
& +\left\{\frac{h^{3}}{60} \cdot \frac{(11+\nu)}{(1-\nu)}-\frac{h^{3}}{60} \cdot \frac{\nu}{(1-\nu)}\right. \\
& \left.+\frac{11 h^{5}}{13440\left(1-\nu^{2}\right)} \nabla^{2}\right\} \rho \ddot{w}_{0, x} \\
& -\frac{(621+555 \nu)}{40320} \cdot \frac{h^{5} \rho^{2(4)}}{E} w_{0, x} \\
& +\frac{D}{R} \nabla^{2} M_{, x}-\frac{D}{T} \nabla^{2} p, x-\frac{h^{2}}{40} \cdot \frac{\nu(3+\nu)}{1-\nu} \\
& \cdot \frac{\rho}{E} \ddot{M}_{, x}+\frac{h^{4}}{22400} \cdot \frac{(191+61 \nu)}{(1-\nu)} \frac{\rho}{E} \ddot{p}_{, x}, \\
& \frac{1}{1+\nu} M-\frac{D}{R} \nabla^{2} M \\
& =-D \nabla^{2} w_{0}-\left\{\frac{12 D}{5 E h}+\frac{D}{T} \nabla^{2}\right\} p \\
& +\frac{D}{S}\left(h \circ \ddot{w}_{0}-\frac{\nu \rho}{2 E} \ddot{M}+\frac{9 h^{2}}{160} \cdot \frac{\rho}{E} \ddot{p}\right) \\
& -\left\{\frac{h^{3} \cdot \nu}{30\left(1-\nu^{2}\right)}-\frac{11 h^{5}}{13440\left(1-\nu^{2}\right)} \nabla^{2}\right\} \rho \ddot{w}_{0} \\
& -\frac{7 h^{3}}{480} \cdot \frac{D}{S} \cdot \frac{\rho^{2}}{E} w_{0}^{(4)} \text {. }
\end{aligned}
$$

ここに,

$$
\left.\begin{array}{l}
D=\frac{E h^{3}}{12\left(1-\nu^{2}\right)}, \quad \frac{D}{R}=\frac{\nu h^{2}}{40\left(1-\nu^{2}\right)}, \\
\frac{D}{S}=\frac{h^{2}}{5(1-\nu)}, \quad \frac{D}{T}=\frac{13 h^{4}}{4480\left(1-\nu^{2}\right)} .
\end{array}\right\}
$$

なお, 式中のコンマ（，）の後の添字はその添字の座

標による偏微分をまた ${ }^{(4)} w_{0}$ は $w_{0}$ の時間 $t$ による 4 階 偏微分を表わす. 式 (4) を特殊化することにより，以下 のように各種の理論式に帰着する.すなわち，まず実線 部を削除すれば $\mathrm{B}-\mathrm{V}$ 理論に一致し，さらに点線部と第 4 式を 削除すれば 動的平板問題の 基本式として 名高い Mindlin 理論でせん断補正係数を $\kappa^{2}=5 / 6$ としたものお よび Schmidt 理論で非線形項を無視したものに一致す る. 他方，第 4 式と実線部および点線部を削除した式に おいて一点鎖線部の項を復活させれば, Ambartsumyan 理論 (A-理論) に一致することになる.

Mindlin 自身の理論の誘導は $\kappa^{2}$ を導入し, せん断力 成分 $Q_{x}, Q_{y}$ と面内変位の線形仮定 : $u=z \beta_{x}(x, y, t)$, $v=z \beta_{y}(x, y, t)$ による断面の回転角 $\beta_{x}, \beta_{y}$ との閒の 関係: 


$$
\left.\begin{array}{l}
Q_{x}=\kappa^{2} G h\left(\beta_{x}+w_{0, x}\right), \\
Q_{y}=\kappa^{2} G h\left(\beta_{y}+w_{0, y}\right) .
\end{array}\right\}
$$

を用いることによって達成されるものであるが，上式を 上述の項の省略によって得られた式に代入すれば，いわ ゆる変位成分 $w_{0}, \beta_{x}, \beta_{y}$ で表示したMindlin 理論の支配 式が次のように求められる ( $\beta_{\boldsymbol{y}}$ に関する支配式は省略).

$$
\begin{aligned}
& \kappa^{2} G h\left(\nabla^{2} w_{0}+e\right)+p=h \rho \ddot{w}_{0}, \\
& \frac{D}{2}\left\{(1-\nu) \nabla^{2} \beta_{x}+(1+\nu) e, x\right\} \\
& \quad-\kappa^{2} G h\left(\beta_{x}+w_{0}, x\right)=\frac{h^{3}}{12} \rho \ddot{\beta}_{x}
\end{aligned}
$$

ここに,

$$
e=\beta_{x, x}+\beta_{y, y}, \quad G=\frac{E}{2(1+\nu)}
$$

ついでながら付言しておくと，上述のように特殊化し て得られた式のうち，A-理論で動的な項をすべて除け ば Reissner 理論 ${ }^{25)}$ に, Mindlin 理論で動的項を削除し, $\kappa^{2}=5 / 6$ とおけば Panc の Component 理論 ${ }^{30)}$ (また $\kappa^{2}=$ 1.0 とすれば Hencky 理論 $\left.{ }^{31)}\right)$ にそれぞれ一致する. さらにその式で平面保持（せん断変形なし）の仮定 : $\beta_{x}=-w_{0, x}, \beta_{y}=-w_{0, y}$ を設定し回転慣性の項を無視 すれば $Q_{x}=-D \nabla^{2} w_{0, x}, Q_{y}=-D \nabla^{2} w_{0, y}$ となり, 平 板の振動を支配する， いわゆる古典理論式 (GermainLagrange の式):

$$
D \nabla^{4} w_{0}=p-h \rho \ddot{w}_{0}
$$

が得られる.

ここで後に変位, 応力状態のモード等の検討に際して 必要となるので, 上記の支配方程式に対応する変位 $u$, $w$, 面内応力 $\sigma_{x}, \tau_{x y}$ を書き下しておけば次のようであ る.

$$
\begin{aligned}
u= & u_{0}-z w_{0}, x+\frac{z}{2 G h}\left\{3-\left(\frac{2 z}{h}\right)^{2}\right\} Q_{x} \\
& +\frac{2 \nu z^{3}}{E h^{3}} M_{, x}+\frac{1}{4 E}\left\{z^{2}-\left(\frac{z^{3}}{h}\right)+\left(\frac{2 z^{5}}{5 h^{3}}\right)\right\} p, x \\
& +\frac{\nu z^{2}}{2 E h} N, x-f(z) \ddot{w}_{0, x}, \\
& \frac{6 \nu z^{2}}{E h^{3}} M-\frac{p}{4 E}\left\{2 z-\left(\frac{3 z^{2}}{h}\right)+\left(\frac{2 z^{4}}{h^{3}}\right)\right\} \\
& -\frac{\nu z}{E h} N+f^{\prime}(z) \ddot{w}_{0} .
\end{aligned}
$$

$$
\begin{aligned}
\sigma_{x}= & \frac{E}{1-\nu^{2}}\left[\left(u_{0, x}+\nu v_{0, y}\right)-z\left(w_{0, x x}+\nu w w_{0}, y y\right)\right. \\
& +\frac{z}{2 G h}\left\{3-\left(\frac{2 z}{h}\right)^{2}\right\}\left(Q_{x, x}+\nu Q_{y, y}\right) \\
& -\frac{\nu(1+\nu)}{4 E}\left\{2-3\left(\frac{2 z}{h}\right)+\left(\frac{2 z}{h}\right)^{3}\right\} p \\
= & =-\underline{-}=-= \\
& =-\nu(1+\nu) f^{\prime \prime}(z) \ddot{w}_{0} \\
& +\frac{2 \nu z^{3}}{E h^{3}}(M, x x+\nu M, y y)
\end{aligned}
$$

$$
\begin{aligned}
& +\frac{1}{4 E}\left\{z^{2}-\left(\frac{z^{3}}{h}\right)+\left(\frac{2 z^{5}}{5 h^{3}}\right)\right\}(p, x x+\nu p, y y) \\
& +\frac{\nu z^{2}}{2 E h}\left(N_{, x x}+\nu N_{, y y}\right) \\
& \left.+f(z)\left(\ddot{w}_{0, x x}+\nu \ddot{w}_{0, y y}\right)\right] \text {, } \\
& \tau_{x y}=G\left[\left(u_{0, y}+v_{0, x}\right)-2 z w_{0, x y}\right. \\
& +\frac{z}{2 G h}\left\{3-\left(\frac{2 z}{h}\right)^{2}\right\}\left(Q_{x, y}+Q_{y, x}\right) \\
& +\frac{4 \nu z^{3}}{E h^{3}} M_{, x y}+\frac{1}{2 E}\left\{z^{2}-\left(\frac{z^{3}}{h}\right)+\left(\frac{2 z^{5}}{5 h^{3}}\right)\right\} p_{, x y} \\
& \left.+\frac{\nu z^{2}}{E h} N_{, x y}+2 f(z) \ddot{w}_{0, x y}\right], \\
& f(z)=\frac{\rho h}{4 E}\left\{\left(\frac{z^{3}}{3 h}\right)-\left(\frac{2 z^{5}}{5 h^{3}}\right)\right\} .
\end{aligned}
$$

これらの式において，先と同様な特殊化により， Mindlin 理論を除くそれぞれのレベルでの理論式の変 位, 応力が求められるのはいうまでもない.

同様に式 (1) の面外方向応力の仮定を基点にして平板 の面内方向 (伸縮) の支配方程式を求めれば次のように なる（v0に関する支配式は省略）.

$$
\begin{aligned}
& \frac{E h}{1-\nu^{2}}\left\{u_{0}, x x+\frac{(1-\nu)}{2} u_{0, y y}+\frac{(1+\nu)}{2} v_{0, x y}\right\} \\
& =h \rho \ddot{u}_{0}+\left\{\frac{h}{2} \cdot \frac{\nu}{(1-\nu)}-\frac{h^{3}}{48\left(1-\nu^{2}\right)} \nabla^{2}\right\} p, x \\
& +\frac{h^{3}}{48} \cdot \frac{\rho}{E} \ddot{p}, x \\
& +\frac{h^{2}}{24} \cdot \frac{\nu}{\left(1-\nu^{2}\right)} \nabla^{2} N_{, x}+\frac{h^{2}}{24} \cdot \frac{\nu \rho}{E} \ddot{N}_{, x} \\
& (1-\nu) N-\frac{\nu h^{2}}{24} \nabla^{2} N \\
& =E h\left(u_{0, x}+v_{0, y}\right)-\left(\nu h-\frac{h^{3}}{48} \nabla^{2}\right) p .
\end{aligned}
$$

ここに, $u_{0}, v_{0}$ は平板中央面（ $z=0$ の面）における $x, y$ 方向の変位成分を表わす. 上式で第 3 式および実 線部を無視すれば $\mathrm{B}-\mathrm{V}$ 理論に，さらに点線部を削除す れば A-理論に，それぞれ一致する. A-理論では面内 直応力成分 $\sigma_{x}, \sigma_{y}$ に $\sigma_{z}$ の影響が具体的な 形で式中に 入るので, 断面力としての軸力 $N_{x}, N_{y}$ に $\sigma_{z}$ （すなわ ち外荷重 $p$ ) の影響が取り込まれ，したがって面内挙動 の支配式に $\partial p / \partial x, \partial p / \partial y$ の項が含まれることになる.

他方 Reissner 理論で動的な項を考慮したものでは, $\sigma_{x}, \sigma_{y}$ が上下逆対称な直線分布で与えられることにな り, 外荷重 $p$ による $N_{x}, N_{y}$ は常に零となってしまう ために， $\sigma_{z}$ の影響が具体的な形で入らず，式中に $p$ の 項は現われない, したがって面内挙動の支配式は， $\sigma_{z}$ の 影響を無視した Schmidt 理論や Mindlin 理論と同様伸 
縮運動をする平板の古典理論式（Poisson の式）とまっ たく同じ次式で表わされる.

$$
\left.\begin{array}{l}
u_{0, x x}+\frac{(1-\nu)}{2} u_{0, y}+\frac{(1+\nu)}{2} v_{0, x y}=\frac{1-\nu^{2}}{E} \rho \ddot{u}_{0} \\
v_{0, y y}+\frac{(1-\nu)}{2} v_{0, x x}+\frac{(1+\nu)}{2} u_{0, x y}=\frac{1-\nu^{2}}{E} \rho \ddot{v}_{0}
\end{array}\right\}
$$

次に著者らの General Higher-Order 理論 ${ }^{29)}$ (G.H. 理論と略称）の概略を述べよう．これは，まず， 3 次元 変位 $u, v, w$ を次式のように板厚方向の座標 $z$ に関し てベキ級数展開できるものと仮定する.

$$
\left.\begin{array}{l}
u=\sum_{n=0}^{\infty} z^{n} \cdot u^{(n)}(x, y, t), \\
v=\sum_{n=0}^{\infty} z^{n} \cdot v^{(n)}(x, y, t), \\
w=\sum_{n=0}^{\infty} z^{n} \cdot w^{(n)}(x, y, t) .
\end{array}\right\}
$$

上式の $u^{(n)}, v^{(n)}$ および $w^{(n)}$ は $n$ 次の変位係数 とよばれる面内座標 $(x, y)$ および時間 $t$ に関する未知 関数である. 式 (15) の変位場を出発点として Hamilton 原理を用いて式の整理を行えば，最終的に，これらの変 位係数で表示した支配方程式が次式のように求められる ( $v^{(m)}$ に関する支配式は省略).

（面外挙動の支配方程式）:

$$
\left.\begin{array}{c}
\sum_{m=1,3, \cdots}^{\infty} B_{m n}\left[G \nabla^{2} u^{(m)}+(\lambda+G) e, x^{(m)}+\{(m+1) \lambda\right. \\
\left.-n G\} w^{\prime}, x^{(m+1)}\right]-2 G\left(\frac{h}{2}\right)^{n} w, x^{(0)} \\
-n G \sum_{m=0,2, \ldots}^{\infty} B_{m, n-1}(m+1) u^{(m+1)} \\
=\rho \sum_{m=1,3, \cdots}^{\infty} B_{m n} \ddot{u}^{(m)}, \quad(n=1,3,5, \cdots \cdots) \\
\sum_{m=0,2, \cdots}^{\infty} B_{m n}\left[G \nabla^{2} w^{(m)}+\{(m+1) G-n \lambda\} e^{(m+1)}\right] \\
-n(\lambda+2 G) \sum_{m=1,3, \cdots}^{\infty} B_{m, n-1}(m+1) w^{(m+1)} \\
=\left(\frac{h}{2}\right)^{n} p+\rho \sum_{m=0,2, \cdots}^{\infty} B_{m n} \ddot{w}^{(m)}, \\
(n=0,2,4, \cdots \cdots)
\end{array}\right\}
$$

（面内挙動の支配方程式）:

$$
\begin{gathered}
\sum_{m=0,2, \cdots}^{\infty} B_{m n}\left[G \nabla^{2} u^{(m)}+(\lambda+G) e, x^{(m)}+\{(m+1) \lambda\right. \\
\left.-n G\} w, x^{(m+1)}\right]-n G \sum_{m=1,3, \cdots}^{\infty} B_{m, n-1}(m+1) u^{(m+1)} \\
=\rho \sum_{m=0,2, \cdots}^{\infty} B_{m n} \ddot{u}^{(m)}, \quad(n=0,2,4, \cdots \cdots) \\
\sum_{m=1,3, \cdots}^{\infty} B_{m n}\left[G \nabla^{2} w^{(m)}+\{(m+1) G-n \lambda\} e^{(m+1)}\right] \\
\cdot 2 \lambda\left(\frac{h}{2}\right)^{n}-e^{(0)}-n(\lambda+2 G)
\end{gathered}
$$

$$
\begin{array}{r}
\cdot \sum_{m=0,2, \cdots}^{\infty} B_{m, n-1}(m+1) w^{(m+1)} \\
=\left(\frac{h}{2}\right)^{n} p+\rho \sum_{m=1,3, \cdots}^{\infty} B_{m n} \ddot{w}^{(m)}, \\
\quad(n=1,3,5, \cdots \cdots)
\end{array}
$$

ここに，

$$
\begin{aligned}
& \lambda=\frac{E \nu}{(1+\nu)(1-2 \nu)}, \\
& B_{m n}=\left(\frac{1}{2}\right)^{m+n} \cdot \frac{h^{m+n+1}}{m+n+1}, \\
& e^{(m)}=u, x^{(m)}+v, y^{(m)} .
\end{aligned}
$$

また，本理論での境界条件を具体的な形で示しておく と，たとえば $x$ 軸に直な境界端面において

$$
\begin{aligned}
& u^{(n)}, \int_{-h / 2}^{h / 2} z^{n} \sigma_{x} d z ; \quad v^{(n)}, \int_{-h / 2}^{h / 2} z^{n} \tau_{x y} d z \\
& w^{(n)}, \int_{-h / 2}^{h / 2} z^{n} \tau_{x z} d z
\end{aligned}
$$

のいずれか一方が規定されることである.

上記の式 (16), (17)，(19) で $u^{(3)}, v^{(3)}, w^{(2)}$ までの 変位係数を採用し, 動的な項を無視すれば Lo らの理 論 $^{32)}$ に完全に一致する. なお変位係数 $u^{(n)}, v^{(n)}, w^{(n)}$ を用いて構成方程式，幾何関係式を通じて忘力成分を決 定すれば著者らの既報の論文 ${ }^{24)}$ の式(19)が求められる.

それらのうち, 面外応力成分 $\sigma_{z}, \tau_{x z}, \tau_{y z}$ はその論文 でも指摘したように，そのままでは上下の境界条件を満 足しないとともに面内応力成分 $\sigma_{x}, \sigma_{y}, \tau_{x y}$ に比べて精 度的にかなり劣ることになるが，これを回避するため， 以下のような手続きによって修正を施すことにする.す なわち物体力を無視した三次元弾性論の運動方程式：

$$
\left.\begin{array}{l}
\sigma_{x, x}+\tau_{x y, y}+\tau_{x z, z}=\rho \ddot{u}, \\
\tau_{x y, x}+\sigma_{y, y}+\tau_{y z, z}=\rho \ddot{v}, \\
\tau_{x z, x}+\tau_{y z, y}+\sigma_{z, z}=\rho \ddot{w} .
\end{array}\right\}
$$

と組み合わせて面外応力成分 $\sigma_{z}, \tau_{x z}, \tau_{y z}$ を決定すれ ば，既報論文 ${ }^{24)}$ の式(28) と同形にるが，それらの式中の $\Gamma_{x}{ }^{(n)}, \Gamma_{y}{ }^{(n)}$ および $\Gamma_{z}{ }^{(n)}$ は次式のように慣性項を含ん だもので与えられる.

$$
\begin{aligned}
\Gamma_{x}{ }^{(n)}=(\lambda+G) e, x^{(n)}+G \nabla^{2} u^{(n)} & \\
& +(n+1) \lambda w, x^{(n+1)}-\rho \ddot{u}^{(n)}, \\
\Gamma_{y}{ }^{(n)}=(\lambda+G) e, y^{(n)}+G \nabla^{2} v^{(n)} & \\
& +(n+1) \lambda w, y^{(n+1)}-\rho \ddot{v}^{(n)}, \\
\Gamma_{z}{ }^{(n)}=(\lambda+2 G) & \nabla^{2} e^{(n)}+(n+1) \lambda \nabla^{2} w^{(n+1)} \\
& -\rho \ddot{e}^{(n)}+(n+1) \rho \ddot{w}^{(n+1)} .
\end{aligned}
$$

この理論では形式上, 無限項の変位係数の採用が可能 であるが，次節の計算例においては実用上の便から $u^{(3)}$, $v^{(3)}, w^{(2)}$ までの項を採用した（3-order）および $u^{(5)}$, 
$v^{(5)}, w^{(4)}$ までの項を採用した (5-order) の 2 種に限定 した場合の例を取り上げることにする.

次に以上の手法とは多少異なった理論構成をもったも ので，最近注目され幾つかの平板やはりの問題への適用 がなされ始めている Vlasov の初期関数法 (MIF) によ

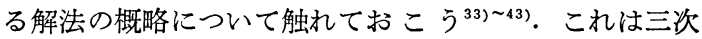
元動弹性学における (運動), (幾何)，(構成）の基礎関 係式からまず, 面内の応力成分 $\sigma_{x}, \sigma_{y}, \tau_{x y}$ を変位 $u$, $v, w$, 応力 $\sigma_{z}, \tau_{x z}, \tau_{y z}$ の項を用いて表示するととも に, これら $u, v, w, \sigma_{z}, \tau_{x z}, \tau_{y z}$ の 6 個の量の間に成 立する微分関係式を導出する. 次に平板内の任意の座標 点 $(x, y, z)$ におけるこれら 6 個の量を板中央面 $(z=0$ の面）のそれぞれの值（初期関数と名付ける）で表示す るために, $z=0$ のまわりに $z$ のべキ乗の形の Maclaurin 級数に展開する. 続いて, 先に導出した微分関係式に上 述の展開式を代入整理し板上下表面 $(z= \pm h / 2)$ での境 界条件から 6 個の初期関数のみの間に成立する二組の微 分方程式系を求める. その一つは面外（曲げ）挙動に関 するものであり，他つ一つは面内（伸縮）挙動に関する むのである. すなわち，微小変形を前提とした等質等方 性の弾性板の場合には，それらは互いに連成せず，独立 な方程式系を形成するが，このことはこれまでに述べた 諸理論による場合ともちろん，同様である．これらの理 論式は任意の次数まで形式的に採用できるようになって おり, 所要の精度が得られるように適当な打切り項数を 設定すればよい (Cheng の論文 ${ }^{44)}$ もこの流れをくむ静的 な平板理論として位置付けされよう).なお，本文では， 他の研究者によってこの理論を用いて得られた動的な問 題に対するデータと，それ以外のここで示した諸理論に よる数値結果との簡単な比較を実施するにとどめること にする.

\section{3. 周辺単純支持矩形板の固有振動解析および 無限板の分散解析}

次節の数値例の提示に先だち 2. に示した各種理論を 用いて

1）周辺単純支持矩形板の固有振動解析，ならびに

2）無限板を伝播する平面調和波の分散解析

を行う場合の固有振動方程式および分散関係式の誘導と それらの具体的な形を示す.

\section{（1）固有振動解析}

まず，最初に B-V 型の理論を取り上げ，固有振動の 解として周辺単純支持の境界条件

$$
\left.\begin{array}{l}
x=0, a \text { において } \sigma_{x}=0, \quad v=0, \quad w=0, \\
y=0, b \text { において } \sigma_{y}=0, \quad u=0, \quad w=0 .
\end{array}\right\}
$$

を満たすように次のごとく仮定する.

曲げ（面外）振動：

$$
\begin{aligned}
& w_{0}=W_{0}{ }^{0} \sin \frac{m \pi x}{a} \sin \frac{n \pi y}{b} \exp \left(i \omega_{m n} t\right), \\
& Q_{x}=Q_{x}{ }^{0} \cos \frac{m \pi x}{a} \sin \frac{n \pi y}{b} \exp \left(i \omega_{m n} t\right), \\
& M=M^{0} \sin \frac{m \pi x}{a} \sin \frac{n \pi y}{b} \exp \left(i \omega_{m n} t\right), \\
& Q_{y}=Q_{y}{ }^{0} \sin \frac{m \pi x}{a} \cos \frac{n \pi y}{b} \exp \left(i \omega_{m n} t\right) .
\end{aligned}
$$

伸縮（面内）振動：

$$
\left.\begin{array}{l}
u_{0}=U_{0}^{0} \cos \frac{m \pi x}{a} \sin \frac{n \pi y}{b} \exp \left(i \omega_{m n} t\right), \\
v_{0}=V_{0}^{0} \sin \frac{m \pi x}{a} \cos \frac{n \pi y}{b} \exp \left(i \omega_{m n} t\right), \\
N=N^{0} \sin \frac{m \pi x}{a} \sin \frac{n \pi y}{b} \exp \left(i \omega_{m n} t\right) .
\end{array}\right\}
$$

これらを式（4）あるいは（13）に代入して整理すれば それぞれ最終的に以下に示すような一般形で表わされた 固有振動方程式が得られる.ただし，ここでは式の簡単 化のために次の略記号を用いることにする。

$$
\alpha=\frac{m \pi}{a}, \quad \beta=\frac{n \pi}{b}, \quad \omega=\omega_{m n}
$$

曲げ（面外）振動：

$$
\left[k_{i j}\right]\left\{W_{0}{ }^{0}, Q_{x^{0}}, Q_{y^{0}}, M^{0}\right\}^{T}=\{0,0,0,0\}^{T}
$$

ここに, 係数マトリックスの各要素 $k_{i j}$ は次のように 与えられる.

$$
\left.\begin{array}{rl}
k_{11}= & -\frac{7 h^{3}}{480} \cdot \frac{\rho^{2}}{E} \omega^{4}-h \rho \omega^{2}, \quad k_{12}=\alpha, \\
k_{13}=\beta, & k_{14}=\frac{\nu \rho}{2 E} \omega^{2}, \\
k_{21}= & \alpha\left[\frac{(621+555 \nu) h^{5}}{40320} \cdot \frac{\rho^{2}}{E} \omega^{4}\right. \\
& +\left\{-\frac{11 h^{5}}{13440} \cdot \frac{\left(\alpha^{2}+\beta^{2}\right)}{\left(1-\nu^{2}\right)} \rho+\frac{h^{3}}{60} \cdot \frac{(11+\nu)}{(1-\nu)} \rho\right. \\
& \left.\left.-\frac{h^{3}}{60} \cdot \frac{\nu}{(1-\nu)} \rho\right\} \omega^{2}-D\left(\alpha^{2}+\beta^{2}\right)\right], \\
k_{22}= & -\frac{h^{2}}{10} \cdot \frac{\rho}{G} \omega^{2}+\frac{h^{2}}{10}\left(\alpha^{2}+\beta^{2}\right)+1, \quad k_{23}=0, \\
k_{24}= & \alpha\left\{-\frac{h^{2}}{40} \cdot \frac{\nu(3+\nu)}{(1-\nu)} \cdot \frac{\rho}{E} \omega^{2}+\frac{D}{R}\left(\alpha^{2}+\beta^{2}\right)\right\}, \\
k_{31}= & \frac{\beta}{\alpha} k_{21}, \quad k_{32}=0, \quad k_{33}=k_{22}, \quad k_{34}=\frac{\beta}{\alpha} k_{24}, \\
k_{41}= & -\frac{7 h^{3}}{480} \cdot \frac{D}{S} \cdot \frac{(1+\nu) \rho^{2}}{E} \omega^{4}+\left\{-(1+\nu) \frac{h D}{S} \rho\right. \\
& \left.+\frac{11 h^{5}}{13440} \cdot \frac{\rho}{(1-\nu)}\left(\alpha^{2}+\beta^{2}\right)+\frac{h^{3}}{30} \cdot \frac{\nu}{(1-\nu)} \rho\right\} \omega^{2}
\end{array}\right\}
$$




$$
\begin{aligned}
& +(1+\nu) D\left(\alpha^{2}+\beta^{2}\right), \\
k_{42}= & k_{43}=0, \\
k_{44}= & \frac{\nu(1+\nu)}{2 E} \cdot \frac{D}{S} \rho \omega^{2}-\left\{\frac{h^{2}}{40} \cdot \frac{\nu}{(1-\nu)}\left(\alpha^{2}+\beta^{2}\right)+1\right\}
\end{aligned}
$$

2. でみたように，これらの係数 $k_{i j}$ を特殊化するこ とにより幾つかの理論の結果と一致することになる.

すなわち，上記に示したすべての項を採用したものが $\mathrm{B}-\mathrm{V}$ 理論に著者らの, 修正を加えたいわゆる修正 $\mathrm{B}-\mathrm{V}$ 理論であり，上式中で実線部および点線部を削除したも のが $\mathrm{B}-\mathrm{V}$ 理論 ${ }^{28)}$ となる. また, $M^{0}$ に関与する部分を すべて取り去った方程式において実線部を削除したもの が $\mathrm{A}$-理論 ${ }^{26)} に$ ささらに，その場合で点線部を削除した

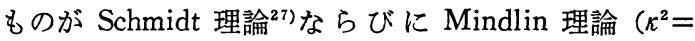
5/6) の固有方程式となる.

伸縮（面内）振動 :

$$
\left[k_{i j}\right]\left\{U_{0}^{0}, V_{0}^{0}, N^{0}\right\}^{T}=\{0,0,0\}^{T} \text {. }
$$

ここに,

$$
\left.\begin{array}{l}
k_{11}=\frac{2}{1-\nu} \alpha^{2}+\beta^{2}-\frac{\rho}{G} \omega^{2}, \quad k_{12}=\frac{1+\nu}{1-\nu} \alpha \beta, \\
k_{13}=\frac{\nu h \alpha}{24 G}\left\{\frac{\left(\alpha^{2}+\beta^{2}\right)}{\left(1-\nu^{2}\right)}-\frac{\rho}{E} \omega^{2}\right\}, \\
k_{21}=k_{12}, \quad k_{22}=\frac{2}{1-\nu} \beta^{2}+\alpha^{2}-\frac{\rho}{G} \omega^{2}, \\
k_{23}=\frac{\nu h \beta}{24 G}\left\{\frac{\left(\alpha^{2}+\beta^{2}\right)}{\left(1-\nu^{2}\right)}-\frac{\rho}{E} \omega^{2}\right\}, \\
k_{31}=E \alpha, \quad k_{32}=E \beta, \quad k_{33}=\frac{1-\nu}{h}+\frac{\nu h}{24}\left(\alpha^{2}+\beta^{2}\right) .
\end{array}\right\}
$$

上記に示したものがいわゆる，修正 B-V 理論である が，上式から $N^{0}$ に関与する項のすべてを削除したもの が B-V 理論, A-理論, Schmidt 理論および古典理論の 4 つの各理論式（固有方程式）となる. 上述の固有方程 式において各末知量 (ベクトル) が有意な解をもつため の条件である係数行列式が零, すなわち $\left|k_{i j}\right|=0$ を $\mathrm{B}-$ V 理論以下のレベルのものについて解くと次のような閉 じた形の $3 つ の$ 無次元化固有振動数パラメーター する解析式が得られる.

$$
\begin{aligned}
& \left.\begin{array}{l}
\lambda_{\mathrm{I}}{ }^{2} \\
\lambda_{\mathrm{II}}{ }^{2}
\end{array}\right\}=\left\{\kappa_{0}+\frac{\left(12+\kappa_{0}\right)-\kappa_{0} \varepsilon_{0} \nu}{6(1-\nu)} \pi^{2} \varphi^{2}\right\} \\
& \pm \sqrt{\left\{\kappa_{0}+\frac{\left(12+\kappa_{0}\right)-\kappa_{0} \varepsilon_{0} \nu}{6(1-\nu)} \pi^{2} \varphi^{2}\right\}^{2}-\frac{4 \kappa_{0} \pi^{4} \varphi^{4}}{3(1-\nu)}}, \\
& \lambda_{\pi^{2}}=2\left(\kappa_{0}+\pi^{2} \varphi^{2}\right) \text {. }
\end{aligned}
$$

$$
\begin{aligned}
& \text { ここに, } \\
& \lambda=\omega h \sqrt{\frac{\rho}{G}}, \varphi=\frac{m h}{a}=\frac{n h}{b}=\frac{\alpha h}{\pi}=\frac{\beta h}{\pi} .
\end{aligned}
$$

なお, 式 (30) の入の下添字 I, II あるいは III の 数字は固有值の小さい方から順に付されたもので, Fig. 2 の一般的なモードの概念図 ${ }^{45}$ において, (a) flexural
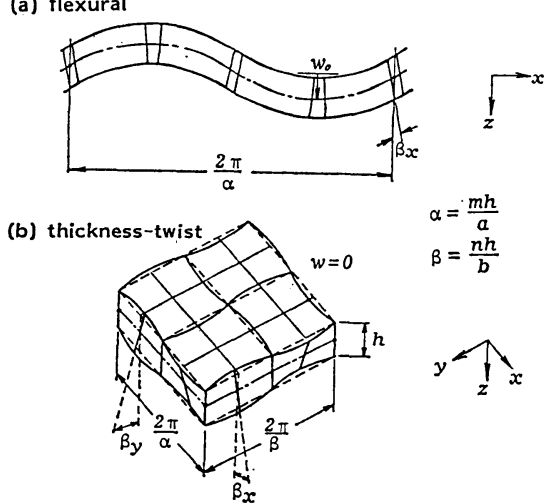

(c) thickness-shear

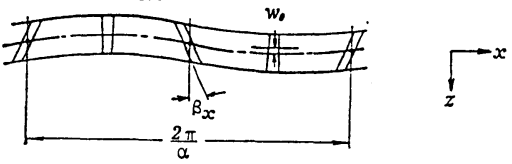

(d) flexural (classical)

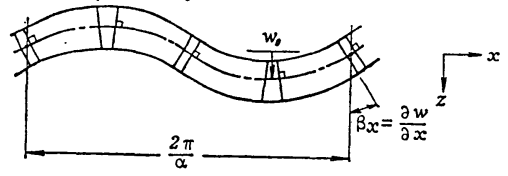

Fig. 2 Schematic figures of antisymmetric modes according to the refined theories and classical theory of simply-supported rectangular plate (After Mindlin et $\mathrm{al}{ }^{45}$ ).

A-I : flexural mode,

A-II : thickness-twist mode,

A-III : thickness-shear mode.

とよばれる各モードに対応するものである．上式中に用 いられている パラメーター $\kappa_{0}$ は Mindlin のせん断補 正係数 $\kappa^{2}$ と $\kappa_{0}=6 \kappa^{2}$ なる関倸にあり $\mathrm{B}-\mathrm{V}$ 理論, $\mathrm{A}$ 理論ならびに Schmidt 理論ではともに $\kappa_{0}=5$ (つまり Mindlin 理論で $\kappa^{2}=5 / 6$ としたものに相当）と置けばよ い. また $\varepsilon_{0}$ は，曲げモーメント和 $M$ の効果による面 外方向の直ひずみ $\varepsilon_{z}$ を考慮するか否かに関係するパラ メーターで, これを考慮する $\mathrm{B}-\mathrm{V}$ 理論では $\varepsilon_{0}=6 / 5$ と なる. 一方, $\varepsilon_{z}$ は考慮しないが面外方向の直応力 $\sigma_{z}$ に おける慣性力の効果 ( $\rho \ddot{w}_{0}$ に関する項) を考慮した $\mathrm{A}$ 理論でも, 結果的には同じく $\varepsilon_{0}=6 / 5$ といら值をとるこ とになる. また, これらを考虑しない Mindlin 理論, Schmidt 理論では $\varepsilon_{0}=1$ とおいてやればよい。

次に G.H. 理論の場合について述べよう. 周辺単純支 持の境界条件 (22) を考慮して, 板の固有振動状態にお ける変位俰数の解を次のように設定する.

$$
\begin{aligned}
& u^{(l)}=U_{l}{ }^{0} \cos \frac{m \pi x}{a} \sin \frac{n \pi y}{b} \exp \left(i \omega_{m n} t\right), \\
& v^{(l)}=V_{l}{ }^{0} \sin \frac{m \pi x}{a} \cos \frac{n \pi y}{b} \exp \left(i \omega_{m n} t\right),
\end{aligned}
$$




$$
w^{(l)}=W_{l}^{0} \sin \frac{m \pi x}{a} \sin \frac{n \pi y}{b} \exp \left(i \omega_{m n} t\right) .
$$

これらを式（16）あるいは（17）に代入し整理すれば 最終的に曲げ（面外）あるいは伸縮（面内）の固有振動 の方程式が次式のように得られることになる.

曲げ (面外) 振動 :

$\left[k_{j l}\right]\left\{\hat{W}_{0}^{0}, \hat{U}_{1}^{0}, \hat{V}_{1}^{0}, \hat{W}_{2}{ }^{0}, \hat{U}_{3}^{0}, \hat{V}_{3}{ }^{0}, \cdots, \hat{U}_{N^{0}}, \hat{V}_{N^{0}}\right\}^{T}$ $=\{0,0, \cdots, 0\}^{T}$

ここに末知量（ベクトル）の要素は

$$
\hat{X}_{l}^{0}=\left(\frac{h}{2}\right)^{l} X_{l}^{0}, \quad X_{l}^{0}=U_{l}^{0}, V_{l}^{0}, W_{l}^{0}
$$

であり，また係数マトリックスの各要素 $k_{j l}(j, l=1$, $2, \cdots, N)$ は次式のように系統的な数式で表示される.

$$
\left.\begin{array}{rl}
k_{3 j-2,3 l-2}= & \frac{2}{2(j+l)-3}\left\{G\left(\alpha^{2}+\beta^{2}\right)-\rho \omega^{2}\right\}\left(\frac{h}{2}\right) \\
& +\frac{2(2 j-2)(2 l-2)}{2(j+l)-5} \cdot(\lambda+2 G) /\left(\frac{h}{2}\right), \\
k_{3 j-1,3 l-1}= & \frac{2}{2(j+l)-1}\left\{(\lambda+2 G) \alpha^{2}+G \beta^{2}-\rho \omega^{2}\right\} \\
& \left.\cdot \frac{h}{2}\right)+\frac{2(2 j-1)(2 l-1)}{2(j+l)-3} G /\left(\frac{h}{2}\right), \\
k_{3 j, 3 l}= & \frac{2}{2(j+l)-1}\left\{(\lambda+2 G) \beta^{2}+G \alpha^{2}-\rho \omega^{2}\right\} \\
\cdot\left(\frac{h}{2}\right)+\frac{2(2 j-1)(2 l-1)}{2(j+l)-3} G /\left(\frac{h}{2}\right), \\
k_{3 j-2,3 l-1}= & \frac{2}{2(j+l)-3}\{(2 l-1) G-(2 j-2) \lambda\} \alpha, \\
k_{3 j-1,3 l-2}= & \frac{2}{2(j+l)-3}\{(2 j-1) G-(2 l-2) \lambda\} \alpha, \\
k_{3 j-2,3 l}=\frac{\beta}{\alpha} k_{3 j-2,3 l-1}, \\
2(\lambda+G) \\
k_{3 j, 3 l-1}=k_{3 j-1,3 l} . h\left(\frac{h}{2}\right), \\
k_{3 j, 3 l-2}=\frac{\beta}{\alpha} k_{3 j-1,3 l-2}, \\
j(j+l)-1
\end{array}\right\}
$$

伸縮（面内）振動：

$$
\begin{aligned}
& {\left[k_{j l}\right]\left\{\hat{U}_{0}{ }^{0}, \hat{V}_{0}{ }^{0}, \hat{W}_{1}{ }^{0}, \hat{U}_{2}{ }^{0}, \hat{V}_{2}{ }^{0}, \cdots, \hat{W}_{N-1}{ }^{0}\right\}^{T}} \\
& =\{0,0, \cdots, 0\}^{T} \text {. }
\end{aligned}
$$

ここに, $k_{j l}$ は式(35) と類似な形式で与えられるが, 紙 面の都合上，ここでは省略する.

これらを数值的に解いて固有振動数, ならびに固有モ ードを求めればよい。

最後に古典理論による固有振動方程式の解を示してお こう. 周辺単純支持矩形板の固有振動の解を式 (23) あ るいは $(24)_{1,2}$ のように仮定し，これらを式 (10) あるい は（14）で外荷重が零, すなわち $p=0$ と置いた固有值 問題の支配式にそれぞれ代入して整理すれば周知のよう
に以下のような固有值が得られることになる.

曲げ (面外) 振動 :

$$
\lambda=\sqrt{\frac{2}{3(1-\nu)}} \pi^{2} \varphi^{2}
$$

伸縮（面内）振動 :

$$
\lambda_{\mathrm{I}}=\sqrt{2} \pi \varphi, \quad \lambda_{\mathrm{I}}=\frac{2 \pi}{\sqrt{1-\nu}} \varphi
$$

上記の式 (37) で与えられる固有値 $\lambda$ は式 (30)の $\lambda_{I}$ すなわち, flexural mode の状態の固有值であって Fig. 2(d) に示したモードがそれに対応する.これは，いわ ゆるせん断変形を考慮した Mindlin 理論のモード (Fig. 2(a)）とはせん断変形の自由度の拘束性が異なるもので ある. なお， Fig. 2 のモード図の板厚方向分布の詳細 については次節で検討する.

\section{（2）分散解析}

$\mathrm{B}-\mathrm{V}$ 理論では無限平板を, 曲げ (面外) モードに対 しては SV 波（鉛直方向の波面を有するせん断波）が， 伸縮 (面内) モードに対してはP波（板面に直な断面方 向の粗密波）が伝播する場合の分散方程式の解としてそ れぞれ次のように仮定してやればよい.

曲げ (面外) モード :

$$
\begin{aligned}
& w_{0}=W_{0}^{0} \exp \left[i k\left(x-c_{\varphi} t\right)\right], \\
& Q_{x}=Q_{x}^{0} \exp \left[i k\left(x-c_{\varphi} t\right)\right], \\
& M=M^{0} \exp \left[i k\left(x-c_{\varphi} t\right)\right] .
\end{aligned}
$$

ここに,

$$
c_{\varphi}=\frac{\omega}{k}, \quad k=\frac{2 \pi}{L}
$$

であって， $c_{\varphi}$ は位相速度， $\omega$ は伝播する波動の振動数, $k$ は波数， $L$ は波長を表わしている.

伸縮（面内）モード：

$$
\left.\begin{array}{l}
u_{0}=U_{0}{ }^{0} \exp \left[i k\left(x-c_{\varphi} t\right)\right], \\
N=N^{0} \exp \left[i k\left(x-c_{\varphi} t\right)\right] .
\end{array}\right\} .
$$

これらを式 (4) $1,2,4$ あるいは (13) 1,3 にそれぞれ代入 すると分散方程式が (1) の固有方程式と類似の形で得ら れるが，ここではそれを省略する．ただし， B-V 理論 以下のレベルの理論では閉じた形の解析式として, 分散 方程式から得られる解を, 位相速度パラメーター $c_{\varphi} / c_{s}$ および振動数パラメーター $\Omega$ についてそれぞれ示すと 最終的に次のように整理された形で求められる.

$$
\begin{aligned}
\left(\frac{c_{\varphi}}{c_{s}}\right)^{2}= & \left\{\frac{\kappa_{0}}{\pi^{2} \xi^{2}}+\frac{\left(12+\kappa_{0}\right)-\kappa_{0} \varepsilon_{0} \nu}{12(1-\nu)}\right\} \\
& \pm \sqrt{\left\{\frac{\kappa_{0}}{\pi^{2} \xi^{2}}+\frac{\left(12+\kappa_{0}\right)-\kappa_{0} \varepsilon_{0} \nu}{12(1-\nu)}\right\}^{2}-\frac{\kappa_{0}}{3(1-\nu)}}
\end{aligned}
$$

$$
\begin{aligned}
\Omega^{2}= & \left\{\frac{\kappa_{0}}{\pi^{2}}+\frac{\left(12+\kappa_{0}\right)-\kappa_{0} \varepsilon_{0} \nu}{12(1-\nu)} \xi^{2}\right\} \\
& \pm \sqrt{\left\{\frac{\kappa_{0}}{\pi^{2}}+\frac{\left(12+\kappa_{0}\right)-\kappa_{0} \varepsilon_{0} \nu}{12(1-\nu)} \xi^{2}\right\}^{2}-\frac{\kappa_{0}}{3(1-\nu)} \xi^{4}}
\end{aligned}
$$


ここに, $c_{s}=\sqrt{G / \rho}$ はせん断波の速度, $\xi=k h / \pi=2 h / L$ は無次元化波数パラメーターであり，また式 (42)，(43) の両パラメーターの間には $\Omega=\xi \cdot c_{\varphi} / c_{s}$ なる関係がある. 次に, G.H. 理論では, 分散方程式の解を

$$
\left.\begin{array}{l}
u^{(l)}=U_{l^{0}} \cdot \exp \left[i k\left(x-c_{\varphi} t\right)\right], \\
w^{(l)}=W_{l}^{0} \exp \left[i k\left(x-c_{\varphi} t\right)\right] .
\end{array}\right\}
$$

のように設定し，これらを式 (16) $)_{1,3}$ あるいは $(17)_{1,3}$ に 代入すれば，曲げ（面外）モード，あるいは伸縮(面内) モードの波動の伝播に関する分散方程式が固有方程式に 類似した形で得られるが，ここでは紙面の都合上その詳 細は省略する.

最後に古典平板理論による分散方程式の解は式 (39) あるいは (41) 1 のように仮定し，これらを式 (10) ある いは $(14)_{1}$ に代入してやれば所期の目的の結果が次のよ うに得られる.

曲げ（面外）モード：

$$
\frac{c_{\varphi}}{c_{s}}=\frac{\pi}{\sqrt{6(1-\nu)}} \xi, \quad \Omega=\frac{\pi}{\sqrt{6(1-\nu)}} \xi^{2} \cdots .
$$

伸縮（面内）モード：

$$
\frac{c_{\varphi}}{c_{s}}=\sqrt{\frac{2}{1-\nu}}, \quad \Omega=\sqrt{\frac{2}{1-\nu}} \xi
$$

\section{4. 数值計算例}

2. で示した各種の理論から得られた計算式 (3. 参照) を用いて幾つかの数值計算を実施した結果を以下に示 し, 各理論のもつ動特性について考察する.

\section{（1） 固有振動特性}

まず, 各理論をもとにして矩形板の固有振動解析を行 った結果を Table 1 および Fig. 3 から Fig. 9 に 示す. Table 1 には $\nu=0.3$ の場合で, モードパラメー ター $\theta\left[=\left(\frac{m h}{a}\right)^{2}+\left(\frac{n h}{b}\right)^{2}=2 \varphi^{2}\right]$ として 225.25 まで の 7 段階の值を与えたときの 固有振動数パラメーター を, 曲げ (面外) 振動に関しては 1 次, 2 次, 3 次（以 後 A-I, A-II, A-III と略記)について, 伸縮（面内） 振動に関しては 1 次, 2 次 (以後 S-I, S-II と略記) についてそれぞれ示したものである. 表中には比較のた めに厳密解 ${ }^{46)}{ }^{47)}$, 古典理論による值, さらに初期関数法

\begin{tabular}{|c|c|c|c|c|c|c|c|c|}
\hline & $\theta$ & 0.02 & 0.18 & 0.50 & 2.00 & 10.40 & 52.00 & 225.25 \\
\hline \multirow{9}{*}{ A-I } & Exact solution & 0.0932 & 0.6889 & 1.5154 & 3.7420 & 9.2894 & 21.0074 & 43.7227 \\
\hline & G.H. theory (5-order) & 0.0932 & 0.6889 & 1.5158 & 3.7421 & 9.3110 & 21.6060 & 46.3661 \\
\hline & G.H. theory (3-order) & 0.0932 & 0.6892 & 1.5186 & 3.7758 & 9.6002 & 22.3286 & 46.9785 \\
\hline & Ambartsumyan, Baluch-Voyiadjis & 0.0931 & 0.6862 & 1.5051 & 3.7006 & 9.1901 & 20.9541 & 43.7826 \\
\hline & refined $B-V$ theory & 0.0931 & 0.6888 & 1.5141 & 3.7059 & 8.8084 & 18.5280 & 36.5853 \\
\hline & Schmidt, Mindlin $\left(\kappa^{2}=5 / 6\right)$ & 0.0931 & 0.6834 & 1.4939 & 3.6536 & 9.0375 & 20.5820 & 42.9942 \\
\hline & Mindlin $\left(\kappa^{2}=\pi^{2} / 12\right)$ & 0.0930 & 0.6821 & 1.4890 & 3.6352 & 8.9819 & 20.4491 & 42.7142 \\
\hline & Classical theory & 0.0963 & 0.8669 & 2.4079 & 9.6317 & 50.0851 & - & - \\
\hline & MIF (8-order) & 0.0932 & 0.6887 & 1.5128 & - & 9.1808 & 20.9223 & 43.6831 \\
\hline \multirow{7}{*}{ A-II } & Exact solution & 3.1729 & 3.4126 & 3.8476 & 5.4414 & 10.6072 & 22.8711 & 47.2547 \\
\hline & G.H. theory (5-order) & 3.1729 & 3.4127 & 3.8477 & 5.4414 & 10.6072 & 22.8711 & 47.2545 \\
\hline & G.H. theory (3-order) & 3.1737 & 3.4135 & 3.8484 & 5.4419 & 10.6075 & 22.8711 & 47.2546 \\
\hline & Ambartsumyan, Baluch-Voyiadjis & 3.1933 & 3.4317 & 3.8646 & 5.4534 & 10.6134 & 22.8740 & 47.2560 \\
\hline & refined $\mathrm{B}-\mathrm{V}$ theory & 3.1933 & 3.4317 & 3.8646 & 5.4534 & 10.6134 & 22.8740 & 47.2560 \\
\hline & Schmidt, Mindlin $\left(\pi^{2}=5 / 6\right)$ & 3.1933 & 3.4317 & 3.8646 & 5.4534 & 10.6134 & 22.8740 & 47.2560 \\
\hline & Mindlin $\left(\kappa^{2}=\pi^{2} / 12\right)$ & 3.1729 & 3.4126 & 3.8476 & 5.4414 & 10.6072 & 22.8711 & 47.2546 \\
\hline \multirow{7}{*}{ A-III } & Exact solution & 3.2465 & 3.9310 & 4.9086 & 7.3956 & 11.2761 & 23.0697 & 47.2921 \\
\hline & G.H. theory (5-order) & 3.2465 & 3.9311 & 4.9088 & 7.4035 & 11.6772 & 23.0930 & 47.3235 \\
\hline & G.H. theory (3-order) & 3.2485 & 3.9438 & 4.9514 & 7.7729 & 13.6603 & 24.7188 & 48.1992 \\
\hline & Ambartsumyan, Baluch-Voyiadjis & 3.2720 & 3.9948 & 5.0590 & 8.2306 & 17.2341 & 37.7926 & 78.3534 \\
\hline & refined $\mathrm{B}-\mathrm{V}$ theory & 3.2701 & 3.9825 & 5.0381 & 8.2574 & 17.8513 & 40.1345 & 83.8126 \\
\hline & Schmidt, Mindlin $\left(\kappa^{2}=5 / 6\right)$ & 3.2741 & 4.0111 & 5.0971 & 8.3366 & 17.5251 & 38.4760 & 79.7865 \\
\hline & Mindlin $\left(\kappa^{2}=\pi^{2} / 12\right)$ & 3.2538 & 3.9926 & 5.0804 & 8.3239 & 17.5181 & 38.4727 & 79.7850 \\
\hline$S-I$ & all theories & 0.4443 & 1.3329 & 2.2214 & 4.4429 & 10.1313 & 22.6542 & 47.1500 \\
\hline \multirow{7}{*}{ S-II } & Exact solution & 0.7498 & 2.2171 & 3.5306 & 5.2013 & 9.5474 & 21.0124 & 43.7274 \\
\hline & G.H. theory (5-order) & 0.7498 & 2.2171 & 3.5307 & 5.2015 & 9.6687 & 22.0416 & 46.7665 \\
\hline & G.H. theory (3-order) & 0.7498 & 2.2193 & 3.5731 & 5.8361 & 10.6420 & 22.8316 & 47.2285 \\
\hline & Ambartsumyan, Baluch-Voyiadjis & 0.7510 & 2.2530 & 3.7549 & 7.5098 & 17.1250 & 38.2929 & 79.6982 \\
\hline & refined B-V theory & 0.7510 & 2.2530 & 3.7549 & 7.5098 & 17.1250 & 38.2929 & 79.6982 \\
\hline & Schmidt & 0.7510 & 2.2530 & 3.7549 & 7.5098 & 17.1250 & 38.2929 & 79.6982 \\
\hline & Classical theory & 0.7510 & 2.2530 & 3.7549 & 7.5098 & 17.1250 & 38.2929 & 79.6982 \\
\hline
\end{tabular}

Table 1 Eigenvalue $\lambda$ for simply-supported rectangular plate $(\nu=0.3)$ with varing mode-parameter $\theta=\left(\frac{m h}{a}\right)^{2}+\left(\frac{n h}{b}\right)^{2}=2 \varphi^{2}$. 
(MIF）による值 ${ }^{34)}$ も併記してある.この表より次のよ うなことが指摘できる.

(1) 曲げ振動の固有值は Mindlin 理論 $\left(\kappa^{2}=5 / 6\right)$ と Schmidt 理論によるものとがまったく同一の值となり, また $\mathrm{A}$-理論と $\mathrm{B}-\mathrm{V}$ 理論によるものとがまったく同一 の值となる. 特に A-II に関してはこれら 4 種の理論に 修正 $\mathrm{B}-\mathrm{V}$ 理論を含めた 5 種の理論による值はすべて同 一となる. さらに Mindlin 自身の提案になる理論 $\left(\kappa^{2}\right.$ $\left.=\pi^{2} / 12\right)$ を加えた 6 種の理論は常にほぼ同等の固有值を 与える.

（2) 伸縮振動の固有值に関しては，すべての場合につ いて修正 B-V 理論, B-V 理論, A-理論, Schmidt 理 論, 古典理論の 5 種類の理論による值がすべて同じにな る.

(3) A-I， A-III および S-II での固有振動数では 各理論による值の差異は $\theta$ の増加とともに増大するのに 対して, A-II での值の差異はかなり大きな $\theta$ になって もほとんどなく, 各理論ともほぼ同じ值となり, さらに S-I に関してはここで計算したすべての理論による值 がまったく同一で，厳密解とも完全に一致する.

(4) 全体的にみて G.H. 理論 (5-order) のものがよ い精度の值を与えている.

(5) 古典理論による值は A-I, S-I および S-II の3つについてのみ存在するが, これらの值は S-I に ついての值を除き $\theta$ の増大とともにかなりの誤差を生じ るようになる.

(6) MIF による值は A-I のみについて示されてい
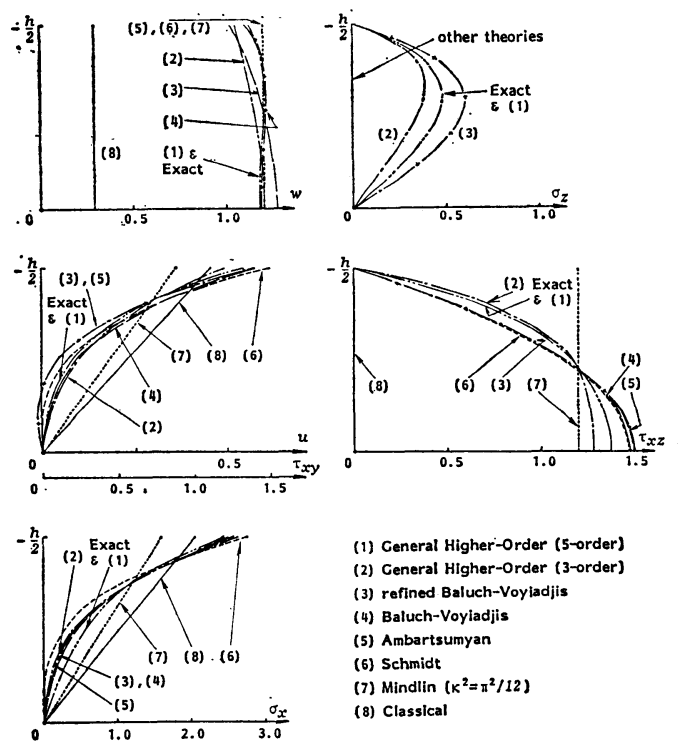

Fig. 3 Distributions of $w, u, \sigma_{x}, \sigma_{z}, \tau_{x z}$ and $\tau_{x y}$ along the thickness for flexural mode (AI) of simply-supported rectangular plate $(\nu=0.3)$ with $\varphi=1.0$.
る ${ }^{36)}$ が，これらの範囲内においてはよい精度の值を示し ている.

なお，G.H. 理論によれば，この表に示した值に加え さらに高次のモード（たとえば 5-order では曲げ 9 次, 伸縮 8 次まで）についての計算值も得られるが，それら の結果に対する精度等の考察はここでは割愛する.

次に Fig. 3 から Fig. 7 には各理論による変位およ び応力の, 板厚方向の分布形 (以下, 板厚モードとよ ぶ)が示されているが, ここでは $\nu=0.3, \varphi=1.0$ (Table 1 の $\theta=2.0$ に対応) の場合に対して, A-I から A-III および S-I と S-II のそれぞれの板厚モードが描かれ ている. なお，ここに示された各力学量の値は同一モー ド内での各力学量間の相互比較ならびに同一力学量の各 モード間での相互比較を可能にするため各理論とも, 系 のエネルギーノルムによって規準化がなされている.

Fig. 3 に示された A-I (flexural mode) の板厚モ 一ドに関しては, Fig. 2(a) の変形のモード図が対応す るものであるが, 各理論による板厚モードのうち古典理 論および Mindlin 理論によるものを除く他の 6 種の理 論によるモードでは $\sigma_{z}$ に関する分布を除き, 目立った 差異はみられず，ほぼ同様の值ならびに傾向を示してお り G.H. 理論 (5-order) によるモードは, ほとんど撖密 解に一致している. Mindlin 理論によるモードは $\kappa^{2}=\pi^{2}$ $/ 12$ の場合と $\kappa^{2}=5 / 6$ の場合との差はほとんどなく同一 の線で示され，ほぼ前述の 6 種の理論による高次変化の 分布を平均的に直線分布に置き換えたものに相当する值 を示しておりこの傾向は次の A-II および A-III にお いても同様の指摘ができる. また, 古典理論による分布 もやはり直線分布であるが, Mindlin 理論での值に比べ 面内変位および面内応力において, より大きい值を示し 面外変位（たわみ）に関しては，ほぼ $1 / 4$ とかなり小さ い值を与えるが，これは静的な場合で正弦分布荷重が作 用した正方形板の $h / a=1.0$ 付近での古典解と他の理論

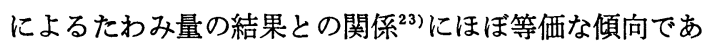
る.

Fig. 4 に示された A-II はいわゆる thickness-twist mode であり Fig. 2(b) の概念図に対応し， $w, \sigma_{z}, \tau_{x y}$ は発生しない.この場合の各種理論による板厚モードで は, B-V 型の 4 種類の理論つまり, 修正 $\mathrm{B}-\mathrm{V}$ 理論, $\mathrm{B}-\mathrm{V}$ 理論, A-理論, Schmidt 理論のものがすべて同一 の值を示し, 他方 G.H. 理論による 5-order と 3-order とがほほ同一の值を示しこれらは厳密解と一致する.さ らにこれら 2 群の線の差異もごく小さい. また, Mindlin 理論での值は A-I の場合と同様, これら 2 群の高次分 布を平均的に直線化したものに相当する值を示し， $\tau_{x z}$ は一様分布となることから, かなりの差異を生ずるもの の $u, \sigma_{x}$ における他の理論との差異はあまり大きくはな 

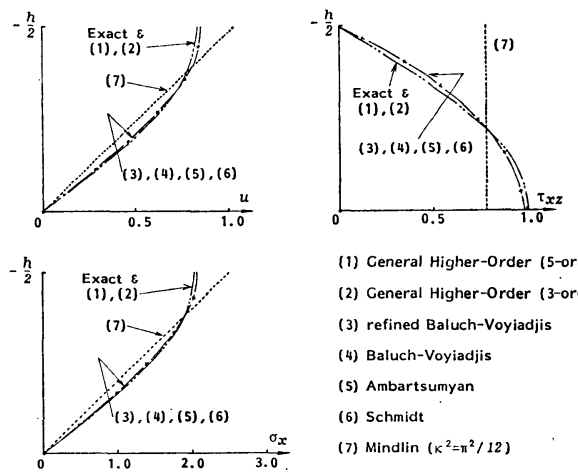

(1) Ceneral Higher-Order (5-order)

(2) General Higher-Order (3-order)

(3) refined Baluch-Voyiadjis

(4) Baluch-Voyiadjis

(5) Ambartsumyan

(6) Schmidt

(7) Mindlin $\left(k^{2}=\pi^{2} / 12\right)$

Fig. 4 Distributions of $u, \sigma_{x}$ and $\tau_{x z}$ along the thickness for thickness-twist mode (A-II) of simply-supported rectangular plate $(\nu=$ 0.3 ) with $\varphi=1.0$.
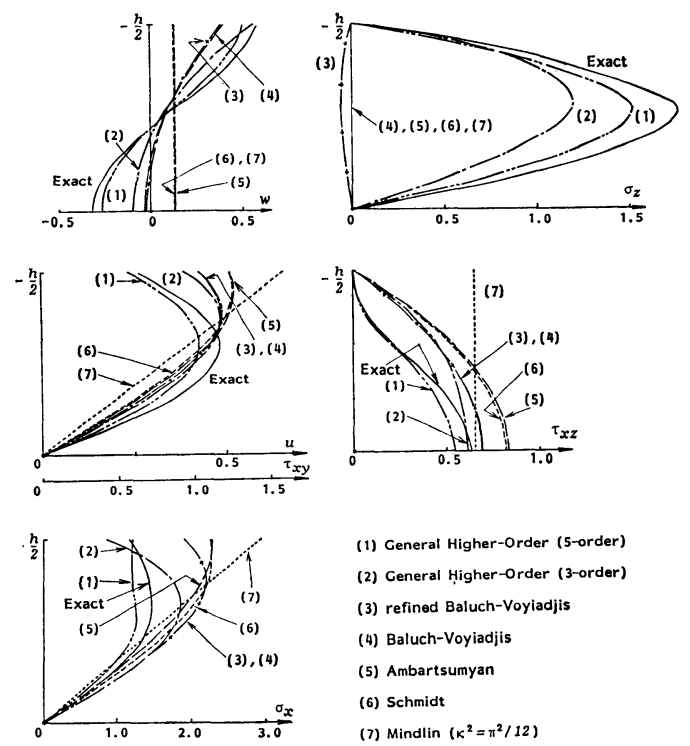

(1) General Higher-Order (5-order)
(2) General Higher-Order (3-order)
(3) refined Baluch-Voyiadjis
(4) Baluch-Voyiadjis
(5) Ambartsumyan
(6) Schmidt
(7) Mindlin $\left(\mathrm{k}^{2}=\pi^{2} / 12\right)$

Fig. 5 Distributions of $w, u, \sigma_{x}, \sigma_{z}, \tau_{x z}$ and $\tau_{x y}$ along the thickness for thickness-shear mode (A-III) of simply-supported rectangular plate $(\nu=0.3)$ with $\varphi=1.0$.

い.

Fig. 5 に示された A-III は thickness-shear mode （Fig. 2(c) に対応）でありwの板厚方向の分布が複雑 に変化し,これに応じて他の力学量の分布形も複雑化 し, $\sigma_{z}$ は他の応力成分と同程度の值をもつ. この板厚モ 一ドでは先の A-I，A-II に比べて各理論間の差異が 大きく生ずる傾向を示している. このうち, 修正 B-V 理論と $\mathrm{B}-\mathrm{V}$ 理論とが, また $\mathrm{A}$-理論と Schmidt 理論 とがそれぞれほぼ同様の值を示す. 全体的にこの板厚モ 一ドにおいて厳密解に近くかつ, より複雑な, あるいは 急激な変化をしている順に並べると， G.H. 理論の 5order, 次に 3-order, 続いて修正 B-V および B-V の 両理論, A-理論および Schmidt 理論, 最後に直線変化

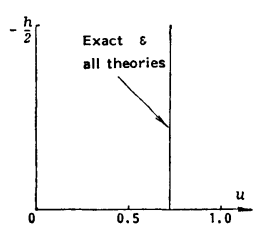

(1) General Higher-Order (5-order)

(2) General Higher-Order (3-order)

(3) refined Baluch-Voyiadjis

(4) Baluch-Voyiadjis

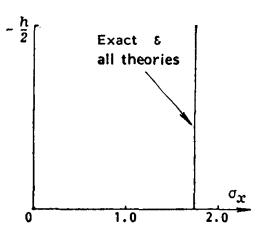

(5) Ambartsumyan

(6) Schmidt

(7) Mindlin $\left(x^{2}=\pi^{2} / 12\right)$

(8) Classical
Fig. 6 Distributions of $u$ and $\sigma_{x}$ along the thickness for extensional mode (S- I ) of simply-supported rectangular plate $(\nu=0.3)$ with $\varphi=1.0$.
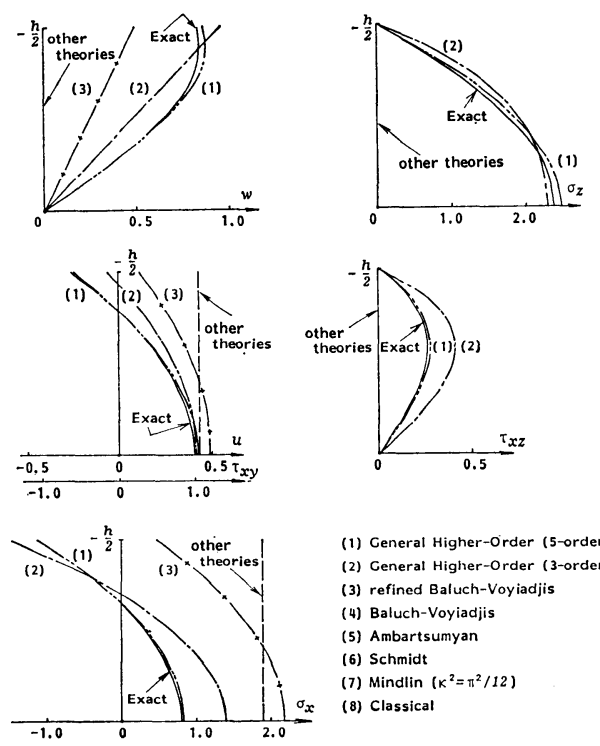

(1) General Higher-Order (5-order) (2) General Higher-Order (3-order) (3) refined Baluch-Voyiadjis

(4) Baluch-Voyiadjis

(5) Ambartsumyan

(6) Schmidt

(7) Mindlin $\left(\mathrm{K}^{2}=\pi^{2} / 12\right)$ (8) Classical

Fig. 7 Distributions of $w, u, \sigma_{x}, \sigma_{z}, \tau_{x z}$ and $\tau_{x y}$ along the thickness for symmetric thickness-shear mode (S-II) of simply-supported rectangular plate $(\nu=0.3)$ with $\varphi=1.0$.

の Mindlin 理論の順となっている. しかしこれら各理 論における値の差異は, 後出の図で示されるように, $\varphi$ の值がより小さくなるにつれて減少していき厳密解にも 近くなっていく.

Fig. 6 に示した S-I の板厚モードは非常に単純な 形であって, 面内の一方向に一様な伸びが生じ, それと 直角方向に一様な同量の縮みが生じる，いわゆる symmetric thickness-twist modeである. このモードに関 してはここに計算したすべての理論による結果は同一で あって, $u, \sigma_{x},\left(\sigma_{y}\right)$ も板厚方向に非零の一様分布とな り, その他の力学量は零となる. このことは Table 1 に揭げたように固有値がすべての理論でまったく同一と なることによっても裏付けられる.

Fig. 7 に示した S-II の symmetric thickness-shear の板厚モードについては, 各理論間で差異が生じてい る. ただし B-V 理論, A-理論, Schmidt 理論, 古典 
理論の 4 種の理論ではまったく同一の値となる.ここで も A-III モードについて述べた傾向と同じく G.H. 理論 の 5-order が最も厳密解に近く, 次に 3-order, 続いて 修正 $\mathrm{B}-\mathrm{V}$ 理論, 最後にすべての力学量が直線分布とな る上記 4 種の理論群の順に，より簡単な分布形となって 精度が落ちてゆくが，これらも後に示すように とともにその差がなくなり，ほぼ同様な値を与えるよう になる。

次に Fig. 8 および Fig. 9 は $\varphi$ の変化に対する前 述の板厚モードのうち A-I における $\sigma_{x}$ の最大值（板 上表面での値)，A-III における $w$ の最大值と最小值(板 上表面と板中央面での値）の，各理論による值の変化を 図示したものである. これらの図から $\varphi$ の值が小さくな るに従って各種理論による值の差は減少しほぼ同じ結果 を与えるようになることが観察される.

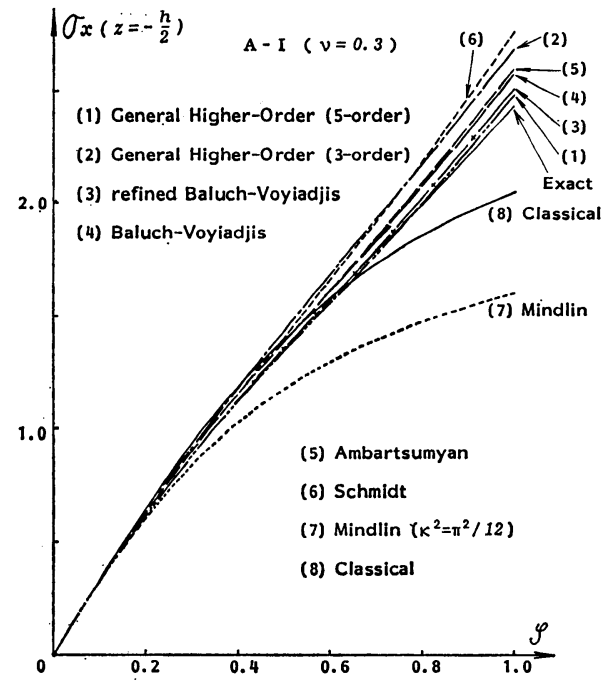

Fig. 8 Relation between $\varphi$ and bending stress $\sigma_{x}$ at upper surface for flexural mode (A-I) of simply-supported rectangular plate $(\nu=0.3)$.

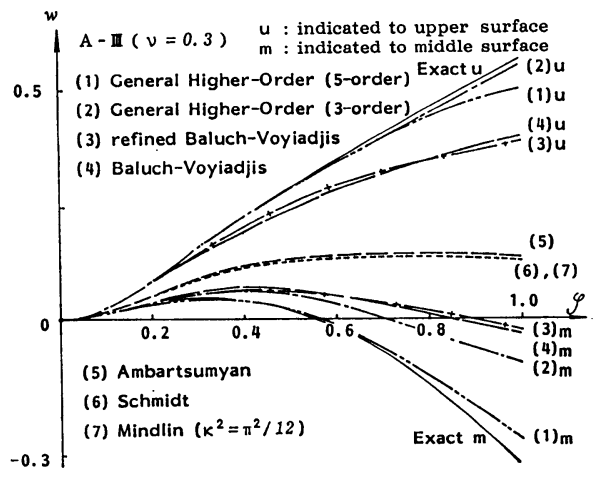

Fig. 9 Relation between $\varphi$ and transverse displacement $w$ at upper and middle surfaces for thickness shear mode (A-III) of simply-supported rectangular plate $(\nu=0.3)$.

\section{（2）分 散特性}

無限板中に SV 波および $\mathrm{P}$ 波が伝播する場合の分散 関係を 2. に示した各種理論により $\nu=0.3$ の場合につ いて求めた結果が Fig. 10 および Fig. 11 である.

Fig. 10 は波数パラメーター $\boldsymbol{\xi}(=2 h / L)$ を変化させた 場合の位相速度 $c_{\varphi}$ を，せん断波の波速 $c_{s}(=\sqrt{G / \rho)}$ と の比として描いたものである.ここでは逆対称モードの 1 次および 2 次，すなわち A-I および A-II（1 次は 前節の板厚モードの A-I に，2 次は A-III にそれぞれ 類似した性状のモード) ならびに対称モードの 1 次, す なわち S-I（前節の板厚モードの S-II に類似した性 状のモード）について示してあるが，これによると，全 体を通じて固有值計算の結果と同じく $\mathrm{B}-\mathrm{V}$ 理論, $\mathrm{A}$-理 論とが，また Schmidt 理論と Mindlin 理論 $\left(\kappa^{2}=5 / 6\right)$ とがそれぞれまったく同一の值を示すとともに Mindlin $\left(\kappa^{2}=\pi^{2} / 12\right)$ とも非常に近い値となっている.

また A-I のモードについてみると， $\boldsymbol{\xi}$ が小さい範囲 では各理論による値に差はなく， $\boldsymbol{\xi}$ が大きくなるとその 差が生じ始める. しかし古典理論による值が $\xi \fallingdotseq 0.2$ よ り大きくなると簃密解 ${ }^{48)}{ }^{49)}$ からはなはだしく離れ，ま た, 修正 $\mathrm{B}-\mathrm{V}$ 理論による值が $\xi \fallingdotseq 3.5$ 以後减少傾向

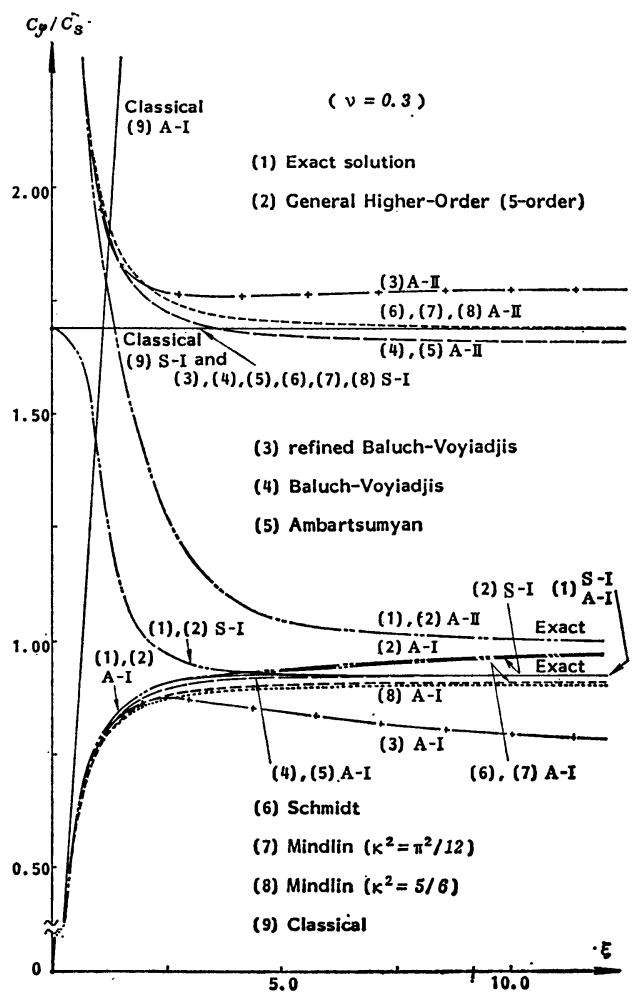

Fig. 10 Dispersion relation (phase velocity spectrum $c_{\varphi} / c_{g}$ versus $\left.\xi\right)$ of an infinite plate $(\nu=0.3)$ with traction free surfaces. 


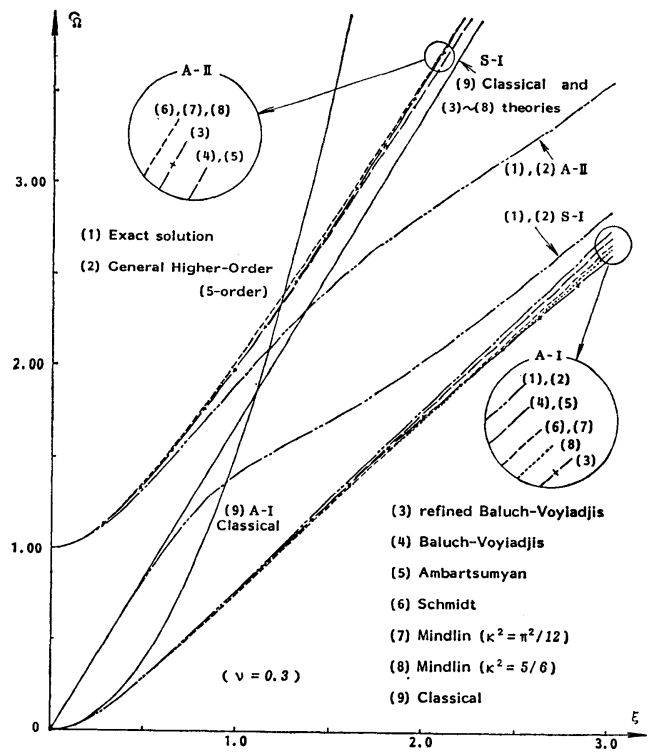

Fig. 11 Dipersion relation (frequency spectrum $\Omega$ versus $\xi)$ of an infinite plate $(\nu=0.3)$ with traction free surfaces.

を呈して，悠密解から離れていく以外は他の各理論とも ほぼ同等の值を示し，かなり厳密解にも近い值となって いる.しかし，A-II のモードでは $\xi \fallingdotseq 0.6$ あたりから 各理論間の差が生じ始め, $\xi \fallingdotseq 3.0$ 以後は修正 $\mathrm{B}-\mathrm{V}$ 理 論, Schmidt 理論および Mindlin 理論 $\left(\kappa^{2}=5 / 6, \kappa^{2}=\right.$ $\left.\pi^{2} / 12\right), \mathrm{B}-\mathrm{V}$ 理論および A-理論は互いに近い值を示し つつ各值ともほぼ変化しなくなる．したがって，この結 果は $\xi \fallingdotseq 10.0$ より大きいところで 1.0 近辺の值に漸近 する厳密解およびこれにきわめて近い值を示す G.H. 理 論の 5-order との間に大きな差を生じることになる.

また， S-I のモードについてみると G.H. 理論の 5-order での值は厳密解との間に, $\xi \fallingdotseq 5.0$ 以後におい てある程度の誤差範囲でよい一致を示しているが，他の すべての理論による值は古典理論とまったく同じで, $\boldsymbol{\xi}$ の值にかかわらず厳密解の $\xi=0.0$ の極限での值に一致 した一定値を示すため大きな誤差を含んだものとなって いる.

次に Fig. 11 は本質的に Fig. 10 と同等であって, この図は $\xi=0$ から $\xi=3.0$ までの間を拡大し $\xi$ の変化 に対する $\mathrm{SV}$ 波の振動数パラメーター $\Omega\left(=c_{\varphi} / c_{s} \xi\right)$ の変 化を描いたものである. この図からも上述の傾向を別の 角度から検証することができる.

\section{5. 結}

本論文では Mindlin 理論をはじめとするいわゆるせ ん断変形を考虑した最近の提案になる幾つかの高次近似
の平板理論に, 古典理論を加えた各種の理論の概要とそ れらの理論間の関連性について検討し, 曲げ（面外）挙 動のみならず伸縮（面内）挙動を含めた単純支持の等質 等方矩形板の固有振動解析および無限板の分散関係につ いて詳細な数值計算を行い各理論式のもつ動特性につい て考察した. ここで得られた成果の一部を挙げれば以下 のようである.

(1) 単純支持の矩形平板に対寸る固有値の定量的な 比較およびそれぞれの振動モードに対する応力, 変位等 の各力学量の板厚方向の分布図を求め, それらの挙動に ついての精度特性を詳細に検討した. また無次元化モ一 ドパラメーター $\varphi$ の変化による代表的な位置での応力, 変位の変動を提示し, 各理論間の関係について比較考察 した.

（2）無限板を伝播する SV 波および $\mathrm{P}$ 波の分散特 性を計算し, それぞれの理論と厳密解との精度比較を行 った.

（3）ここで実施した固有振動解析および分散関係の 両者を通じ，対象として取り上げた各種の近似理論のう ち G.H. 理論の 5-order のものが全般的にきわめて精 度のよい結果を与えることが判明した。

\section{参考 文 献}

1) Leissa, A.W. : Vibration of plates, NASA SP-160, U.S. Govt. Printing Office, 1969.

2) Leissa, A.W. : The free vibration of rectangular plates, J. Sound Vib., Vol. 31, pp. 257 293, 1973.

3) Leissa, A.W. : Recent research in plate vibrations : classical theory, Shock Vib. Dig., Vol. 9, pp. 13 24, 1977.

4) Leissa, A.W. : Recent research in plate vibrations. 1973-1976 : complicating effects, Shock Vib. Dig., Vol. 10 , pp. $21 \sim 35,1978$. ; Plate vibration research, 19761980 : complicating effects, Shock Vib. Dig., Vol. 13(10) pp. 19 36, 1981.

5) Bert, C.W. : Recent research in composite and sandwich plate dynamics, Shock Vib. Dig., Vol. 11 pp. 13 $\sim 23,1979$.; Research on dynamics of composite and sandwich plates, 1979-81, Shock Vib. Dig., Vol. 14 (10) pp. 17 34, 1982.

6) Todhunter, I. : A history of the theory of elasticity, Vol. 1, Dover, pp. 147 160, 1960.; Vol. 2, Part 2, Dover, pp. 39 107, 1960.

7) Timoshenko, S.P. (川口昌宏訳) : 材料力学史, 鹿島出 版, pp. 108 112, pp. 226 229, 1974.

8) Love, A.E.H. : A treatise on the mathematical theory of elasticity, 4th edition, Dover, pp. 1 31, 1944.

9) Westergaard, H.M. : Theory of elasticity and plasticity, Dover, pp. 8 45, 1952.

10) Pao, Y.H. and R.K. Kaul : Waves and vibrations in isotropic and anisotropic plates, R.D. Mindlin and Applied Mechanics (ed. by G. Herrmann), Pergamon Press, pp. 149 195, 1973.

11) Naghdi, P.M. : The theory of shells and plates, in Encyclopedia of Physics (ed. by S. Flügge), Vol. VIa/2, Springer pp. 425 640, 1972. 
12) Bell, J.F.: The experimental foundations of solid mechanics, in Encyclopedia of Physics (ed. by S. Flügge), Vol. VIa/1, Springer, 1973.

13) Rayleigh, L.: On the free vibrations of an infinite plate of homogeneous isotropic elastic matter, Proc. Lond. Math. Soc., Vol. 20, pp. 225 234, 1889.

14) Lamb, H. : On waves in an elastic plate, Proc. Roy. Soc., London, Ser. A 93, pp. 114 128, 1917.

15) Rayleigh, L. : The theory of sound, Two Vol., Dover, 1960.

16) 前出 8)

17）吉川昭吉郎：通信革命を担う弾性表面波, 科学朝日, pp. $65 \sim 69,1980-11$.

18) Mindlin, R.D. : Influence of rotatory inertia and shear on flexural motions of isotropic, elastic plates, J. Appl. Mech., pp. 31 38, 1951.

19) Mindlin, R.D. : Thickness-shear and flexural vibrations of crystal plates, J. Appl. Phys., Vol. 22, pp. 316 323, 1951.

20) Mindlin, R.D.: An introduction to the mathematical theory of vibrations of elastic plates, U.S. Army Signal Corps. Eng. Lab., Fort Monmouth, 1955.

21) Herrmann, G. (ed.) : R.D. Mindlin and Applied Mechanics, Pergamon Press, 1973.

22) Dökmeci, M.C. : Recent advances-Vibrations of piezoelectric crystals, Int. J. Eng. Sci., Vol. 18, pp. 431 $\sim 448,1980$.

23）根岸嘉和・平島健一：せん断変形を考虑した一連の平板 曲げの理論について, 山梨大学工学部研究報告, No. 32 , pp. $28 \sim 42,1981$.

24）平島健一・根岸嘉和：板厚方向の成分を考虑した代表的 な 2 次元化平板理論の精度に関する考察, 土木学会論文 報告集，第330 号，pp. 1 14，1983-2.

25) Reissner, E. : The effects of transverse shear deformation on the bending of elastic plates, J. Appl. Mech. pp. A 69 A 77, 1945.

26) Ambartsumyan, S.A. (神谷紀生訳)：異方弹性板の理論, 森北出版, pp. 175 187, 1975.

27) Schmidt, R. : A refined nonlinear theory of plates with transverse shear deformation, J. Indust. Math. Soc., Vol. 27, pp. 23 38, 1977.

28) Voyiadjis, G.Z. and Baluch, M.N. : Refined theory for flexural motions of isotropic elastic plates, J. Sound Vib., Vol. 76, pp. 57 64, 1981.

29) Hirashima, K., P.C.Y. Lee and Y. Negishi : General Higher-Order Equations of Two-Dimensional Static and Dynamic Theories for Homogeneous and Laminated Elastic Plates, Proc. Ninth U.S. National Congr. of Appl. Mech., Ithaca, Cornell Univ., p. 476, 1982.; 平島健一・根岸嘉和：異方性・層状性を考慮した平板の 高次近似理論, 土木学会 年次学術講演会概要集第 1 部, pp. $29 \sim 30,1981$.

30) Panc, V. : Theories of elastic plates, Noordhoff Int. Pub., pp. 13 356, 1974.
31) Hencky, H. : Über die Berucksichtigung der schubverrung in ebenen platten, Ing. Arch., Vol. 16, pp. $72 \sim 76,1947$.

32) Lo, K.H., R.M. Christensen and E.M. Wu : A high order theory of plate deformation, J. Appl. Mech., pp. 663 676, 1977.

33) Vlasov, V.Z. : The method of initial function in problems of theory of thick plates and shells, Proc. 9th Int. Cong. Appl. Mech., Vol. 6, pp. 321 330, 1956.

34) Das, Y.C. and A.V. Setlur : Method of initial functions in two-dimensional elastodynamic problems, J. Appl. Mech. pp. 137 140, 1970.

35) Iyenger, K.T.S.R., K. Chandrashekhara and V.K. Sevastian : On the analysis of thick rectangular plates, Ing. Arch., Vol. 43, pp. 317 330, 1974.

36) Iyenger, K.T.S.R. and P.V. Raman : Free vibration of rectangular plates of arbitrary thickness, J. Sound Vib., Vol. 54, pp. 229 236, 1977.

37) Rao, N.S.V.K. and Y.C. Das : A mixed method in elasticity, J. Appl. Mech., pp. 51 56, 1977.

38) Celep, $Z$.: On the axially symmetric vibration of thick circula plates, Ing. Arch., Vol. 47, pp. 411 420, 1978.

39) Iyenger, K.T.S.R. and P.V. Raman : Free vibration of circular plates of arbitrary thickness, J. Acoust. Soc. Am., Vol. 64, pp. 1088 1092, 1978.

40) Celep, Z. : Free vibration of some circular plates of arbitrary thickness, J. Sound Vib., Vol. 70, pp. 379 388,1980

41) Celep, Z.: On the elastodynamic theory of thick circular plates, ZAMM, Vol. 60, pp. 323 333, 1980.

42) Iyenger, K.T.S.R., K. Chandrashekhara and V.K. Sevastian : Thick rectangular beams, J. EM Div., Proc. ASCE, Vol. 100, pp. 1277 1282, 1974.

43) Iyenger, K.T.S.R. and P.V. Raman : Free vibration of rectangular beams of arbitrary depth, Acta Mech., Vol. 32, pp. 249 259, 1979.

44) Chen, S. : Elasticity theory of plates and a refined theory, J. Appl. Mech., pp. 644 650, 1979.

45) Mindlin, R.D., A. Schacknow and H. Deresiewicz: Flexural vibrations of rectangular plates, J. Appl. Mech., pp. 430 436, 1956.

46) Lee, Y. C. and H. Reismann: Dynamics of rectangular plates, Int. J. Eng. Sci., Vol. 7, pp. 93 113, 1969.

47) Srinivas, S., C.V.J. Rao and A.K. Rao : An exact analysis for vibration of simply-supported homogeneous and laminated thick rectangular plates, J. Sound Vib., Vol. 12, pp. 187 199, 1970.

48) Potter, D.S. and C.D. Leedham : Normalized numerical solutions for Rayleigh's frequency equation, J. Acoust. Soc. Am., Vol. 41, pp. 148 153, 1967.

49) Dong, S.B. and R.B. Nelson : On natural vibrations and waves in laminated orthotropic plates, J. Appl. Mech., pp. 739 745, 1972.

(1982.2.26 • 受付) 